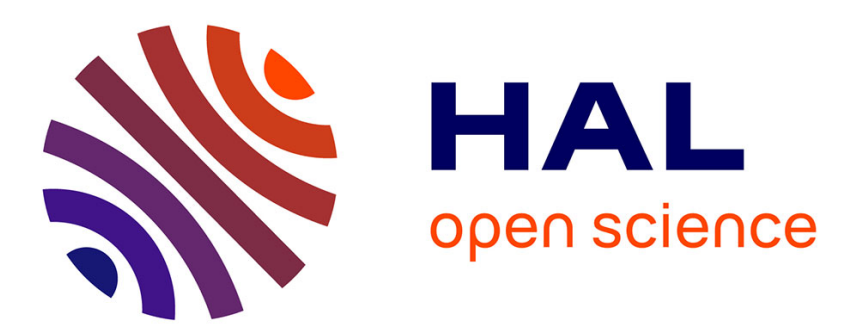

\title{
Influence of tantalum on the rates of high temperature oxidation and chromia volatilization for cast (Fe and/or $\mathrm{Ni})-30 \mathrm{Cr}-0.4 \mathrm{C}$ alloys
}

\author{
Patrice Berthod, Yassin Hamini, Lionel Aranda
}

\section{- To cite this version:}

Patrice Berthod, Yassin Hamini, Lionel Aranda. Influence of tantalum on the rates of high temperature oxidation and chromia volatilization for cast (Fe and/or $\mathrm{Ni}$ )-30Cr-0.4C alloys. Materials Science Forum, 2008, High Temperature Corrosion and Protection of Materials 7, 595-598, pp.861870. 10.4028/www.scientific.net/MSF.595-598.861 . hal-02275492

HAL Id: hal-02275492

https://hal.science/hal-02275492

Submitted on 30 Aug 2019

HAL is a multi-disciplinary open access archive for the deposit and dissemination of scientific research documents, whether they are published or not. The documents may come from teaching and research institutions in France or abroad, or from public or private research centers.
L'archive ouverte pluridisciplinaire HAL, est destinée au dépôt et à la diffusion de documents scientifiques de niveau recherche, publiés ou non, émanant des établissements d'enseignement et de recherche français ou étrangers, des laboratoires publics ou privés. 


\title{
Influence of tantalum on the rates of high temperature oxidation and chromia volatilization for cast (Fe and/or $\mathrm{Ni}$ )-30Cr-0.4C alloys
}

\author{
Patrice Berthod, Yassin Hamini and Lionel Aranda \\ Laboratoire de Chimie du Solide Minéral (UMR 7555), Faculté des Sciences et Techniques, \\ Université Henri Poincaré Nancy 1, Nancy-Université \\ BP 239, 54506 Vandoeuvre-Les-Nancy Cedex, France \\ patrice.berthod@ centraliens-lille.org
}

Post-print version of the article: Materials Science Forum (2008) Vols. 595-598, pp.861 -870

Keywords: Cast alloys, High temperature oxidation, Chromia volatilization, Tantalum carbides

\begin{abstract}
Four cast superalloys, Fe-base and (Fe,Ni)-base alloys, all containing 30\% Cr and 0.4\%C, were elaborated with addition of $3 \%$ and $6 \%$ of tantalum. Their oxidation behaviours were studied at $1,000,1,100$ and $1,200^{\circ} \mathrm{C}$ during 50 hours. The oxidized surfaces of the samples were quantitatively characterized by measurements of thicknesses and surface fractions of internal oxides. The thermogravimetry files were treated according to the $\{m \times(d m / d t)=K p-K v \times m\}$ equation, to obtain simultaneously the parabolic constant and the chromia volatilization constant. The internal tantalum oxides are more present in the Fe-base alloys and the carbide-free zones are less developed for the (Fe,Ni)-base alloys than for the others. The Fe-base alloys oxidize faster than the (Fe,Ni)-base and Ni-base alloys. The comparison with the corresponding Ta-free ternary alloys shows that the presence of Ta tends to accelerate the oxidation.
\end{abstract}

\section{Introduction}

The equiaxed superalloys obtained by classical foundry process are often reinforced by the presence of both interdendritic carbides appeared during solidification, and eventually also by secondary carbides obtained by applying a specific heat treatment. It is notably the case of cobalt-base alloys, but this principle of strengthening can also be used for nickel and iron-base alloys. Thus, in addition to chromium, the role of which is to bring a good resistance against high temperature oxidation to the conventionally cast superalloys [1], tantalum, which is also a very oxidable element, can play a role in the high temperature oxidation of ( $\mathrm{Fe}$ and/or $\mathrm{Ni}$ ) -base alloys.

In this work the high temperature oxidation behaviours of two iron-base alloys and two ironnickel base alloys, containing $0.4 \% \mathrm{C}$ and two amounts of tantalum $3 \%$ and $6 \%$, are studied, with comparison with results obtained previously for ternary $\mathrm{M} 30 \mathrm{Cr} 0.4 \mathrm{C}$ alloys [2] and two nickel-base alloys with $0.4 \mathrm{C}$ and $3 \%$ to $6 \% \mathrm{Ta}$ [3].

\section{Experimental Procedures}

Elaboration of the alloys and thermogravimetry runs. Two Fe-base and two (Fe,Ni)-base alloys, containing 3 and $6 \mathrm{wt}$ \% of tantalum (Table 1), were melt by HF induction and solidified in a watercooled copper crucible under pure argon (300mbar), to obtain ingots of about $100 \mathrm{~g}$ from graphite and pure $\mathrm{Fe}, \mathrm{Ni}, \mathrm{Cr}$ and $\mathrm{Ta}\left(>99.9 \%_{\mathrm{w}}\right.$, Alfa Aesar). The geometry of the samples for thermogravimetry experiments was about $2 \times 10 \times 10 \mathrm{~mm}^{3}$. All samples were polished with SiC paper up to 1,200 grid. A Setaram TGA92 thermobalance was used to perform the thermogravimetric analyses, at $1,000^{\circ} \mathrm{C}, 1,100^{\circ} \mathrm{C}$ and $1,200^{\circ} \mathrm{C}$ during 50 hours under a dry industrial air flow at 1.5 $\mathrm{L} / \mathrm{h}$. The heating was realized at $20^{\circ} \mathrm{C} / \mathrm{min}$ and the cooling after test at $-10^{\circ} \mathrm{C} / \mathrm{min}$. 
Metallography characterization. After the thermogravimetry runs, the oxidized samples were coated by a cathodic evaporated gold film in order to allow the electrolytic deposition of nickel on their external oxide scale (when it remained on surface after cooling), to protect the latter against stresses due to cutting. The samples were cut and embedded in a cold resin, then polished with $\mathrm{SiC}$ paper from 80 to 1,200 grid under water, then finished with a diamond paste $6 \mu \mathrm{m}$. The samples were examined using a Scanning Electron Microscope (SEM) Philips XL30. Generally it was done in the Back Scattered Electrons mode (BSE) and by using an accelerating voltage of $20 \mathrm{kV}$. The Energy Dispersion Spectrometry device (EDS) of the SEM allowed analyzing the chemical composition of each sample in three different locations. This permitted the calculation of an average content for each element with its corresponding standard deviation value (results displayed in Table 1). The thickness of the chromia scales (or of the parts of this scale remaining on surface after cooling) and the depth of the carbide-free zones were measured in three locations and the average value was calculated. The internal oxidation was characterized by measuring, on three SEM micrographs of the sub-surface, the surface fraction of the sub-cortical oxides involving tantalum. These ones appear as white particles when they are observed in BSE mode. The average value of an equivalent thickness for this oxide was calculated according to Eq. 1 in which $1_{\text {phot }}$ is the length of the area covered by the micrograph and $f_{S}$ is the surface fraction of the white tantalum oxides determined using the Photoshop CS software.

$$
\mathrm{e}_{(\mathrm{Cr}, \mathrm{Ta}) \text { oxide }}=1_{\text {phot }} \times \mathrm{f}_{\mathrm{s}} \text {. }
$$

Kinetic constants of oxidation. The mass gain results must be first corrected from the progressive loss of carbon from the external surface which was oxidized into gaseous species. Indeed, thermodynamic calculations can show that the carbide-free zone which develops from the oxidation front cannot contain carbon. Correction was performed by adding, to the recorded files, the term $\mathrm{R}_{\mathrm{C}}(\mathrm{t})$ expressed in Eq. 2 representing the mass of lost carbon versus time (following a law supposed to be parabolic). In Eq. 2, $\rho_{\text {alloy }}$ is the density of the alloy, $S$ the external surface of the sample, $d_{c f z}$ the final depth of the carbide-free zone, $\%_{\mathrm{w}} \mathrm{C}_{\text {alloy }}$ the carbon weight content of the alloy, $\mathrm{t}$ the time spent after the beginning of the isothermal stage and $\Delta \mathrm{t}_{\text {stage }}$ the total duration of this stage.

$$
\mathrm{R}_{\mathrm{C}}(\mathrm{t})=\rho_{\text {alloy }} \times \mathrm{S} \times \%_{\mathrm{w}} \mathrm{C}_{\text {alloy }} \cdot \mathrm{d}_{\mathrm{cfz}} \times \sqrt{\frac{\mathrm{t}}{\Delta \mathrm{t}_{\text {stage }}}} .
$$

The first oxidation constant $\mathrm{K}_{1}$, which characterizes the transient oxidation, corresponds to the slope of the straight line obtained at the beginning of the isothermal mass gain curves before the beginning of the actual parabolic oxidation. The parabolic constant $\mathrm{Kp}$ and the constant of chromia volatilization $\mathrm{Kv}$ were determined by using the method defined in an earlier work [4]. This was done by considering that the $\mathrm{Kp}$ and $\mathrm{Kv}$ constants are respectively equal to the ordinate at the origin and to the slope of the obtained straight line which appears when the thermogravimetry results are plotted according to Eq. 3 (in which $\mathrm{m}$ is the mass gain per unit area). The validity of these values was thereafter verified by comparing the experimental mass gain curve and the mathematical curve plotted using the obtained constants.

$$
\mathrm{m} \times \frac{\mathrm{dm}}{\mathrm{dt}}=\mathrm{Kp}-\mathrm{Kv} \times \mathrm{m}
$$

\section{Results}

Chemical compositions and microstructures. Table 1 presents the obtained compositions of the four studied alloys, measured by EDS analysis on three x250 areas. By considering the standard 
deviations, the targeted compositions appear to be well respected. The as-cast alloys present microstructures which are composed of a dendritic matrix and interdendritic carbides. The latter are exclusively tantalum carbides $(\mathrm{TaC})$. These Fe-base and (Fe,Ni)-base alloys contain much more tantalum carbides than the corresponding Ni-base alloys with similar compositions [3] which contained both chromium and tantalum carbides.

Table 1. The obtained chemical compositions for the alloys (average values \pm standard deviation)

\begin{tabular}{|c|c|c|c|c|c|}
\hline Weight contents [\%] & $\mathrm{Fe}$ & $\mathrm{Ni}$ & $\mathrm{Cr}$ & $\mathrm{Ta}$ & $\mathrm{C}$ \\
\hline Fe30Cr0.4C3Ta & Bal. & $/$ & $29.5 \pm 2.7$ & $2.4 \pm 0.4$ & $\approx 0.4$ \\
\hline Fe30Cr0.4C6Ta & Bal. & $/$ & $29.2 \pm 1.6$ & $6.2 \pm 1.1$ & $\approx 0.4$ \\
\hline FeNi30Cr0.4C3Ta & Bal. & $34.0 \pm 0.4$ & $30.0 \pm 0.3$ & $2.8 \pm 0.4$ & $\approx 0.4$ \\
\hline FeNi30Cr0.4C6Ta & Bal. & $32.5 \pm 0.2$ & $29.5 \pm 0.3$ & $6.4 \pm 0.3$ & $\approx 0.4$ \\
\hline
\end{tabular}

Surface microstructural states of the alloys after oxidation. The sub-surface microstructures of the oxidized alloys are illustrated by Fig. 1 (Fe-base alloys) and Fig. 2 (FeNi-base alloys), for the two extreme temperatures. The tantalum carbides which were initially present before test, disappeared from the oxidation front over a depth which increases with the temperature of the thermogravimetric test. The part of the alloys that is just under the external surface is affected by an internal oxidation that leads to dispersed "islands" of oxides of both chromium and tantalum. These ones seem to be denser and more developed for the alloys with 6\% Ta than for the ones with only $3 \% \mathrm{Ta}$, and for $1,200^{\circ} \mathrm{C}$ and $1,100^{\circ} \mathrm{C}$ than for $1,000^{\circ} \mathrm{C}$. There is also an external oxide scale, which remains sometimes adherent. This layer is mainly constituted of chromia $\mathrm{Cr}_{2} \mathrm{O}_{3}$ but it can also contain films or particles of tantalum oxides.
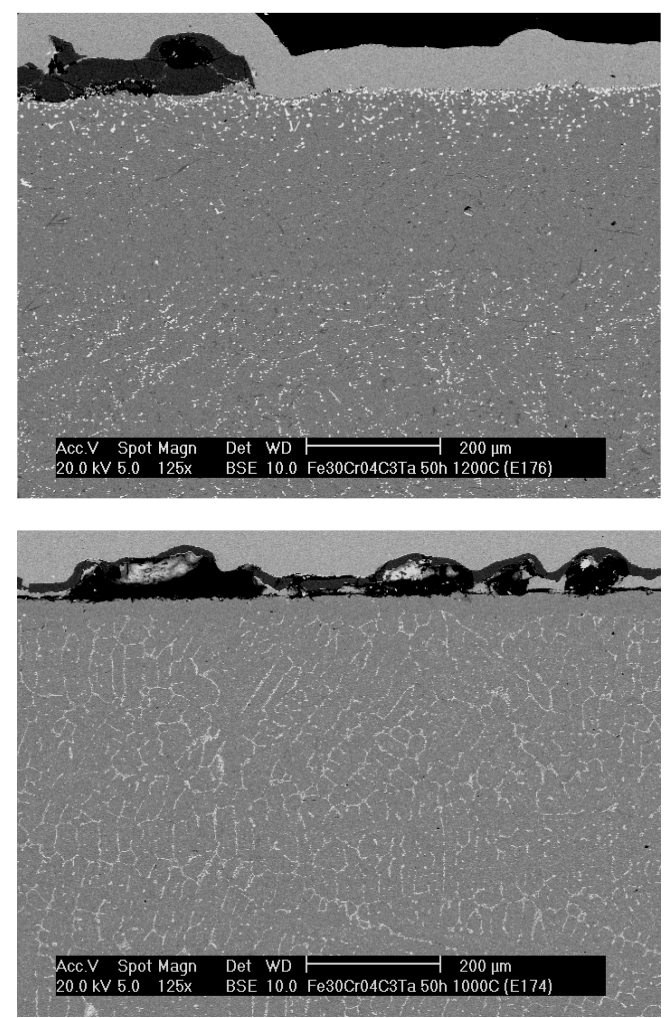

Fe30Cr0.4C3Ta
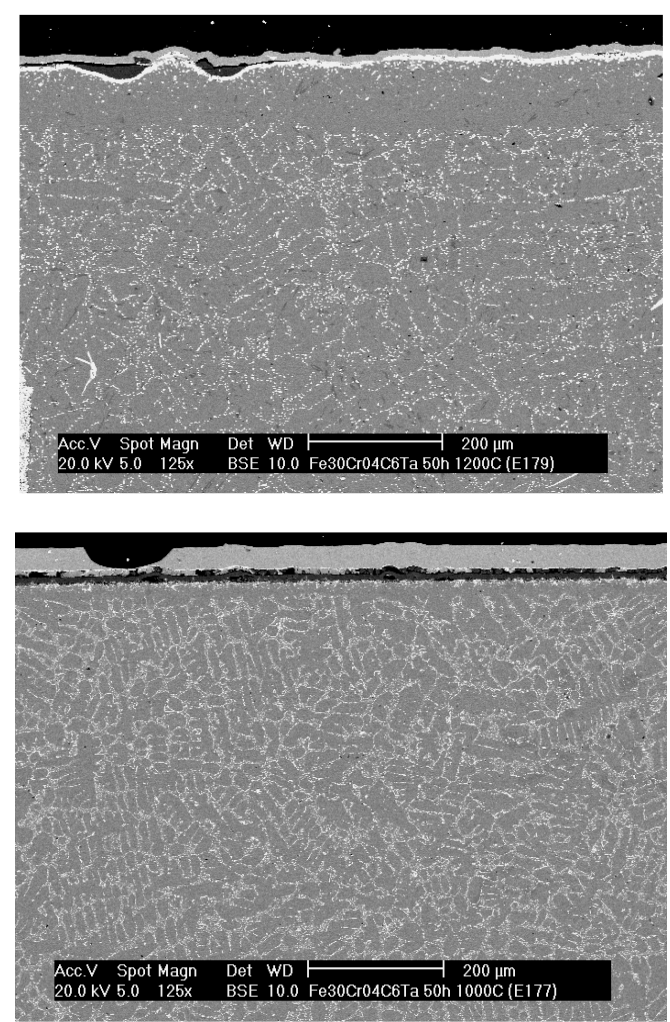

Fe30Cr0.4C6Ta

Fig. 1. Cross section metallographies of the two Fe-base alloys containing Ta after oxidation for 50 hours at the two extreme temperatures $1,200^{\circ} \mathrm{C}$ (top) and $1,000^{\circ} \mathrm{C}$ (bottom) 

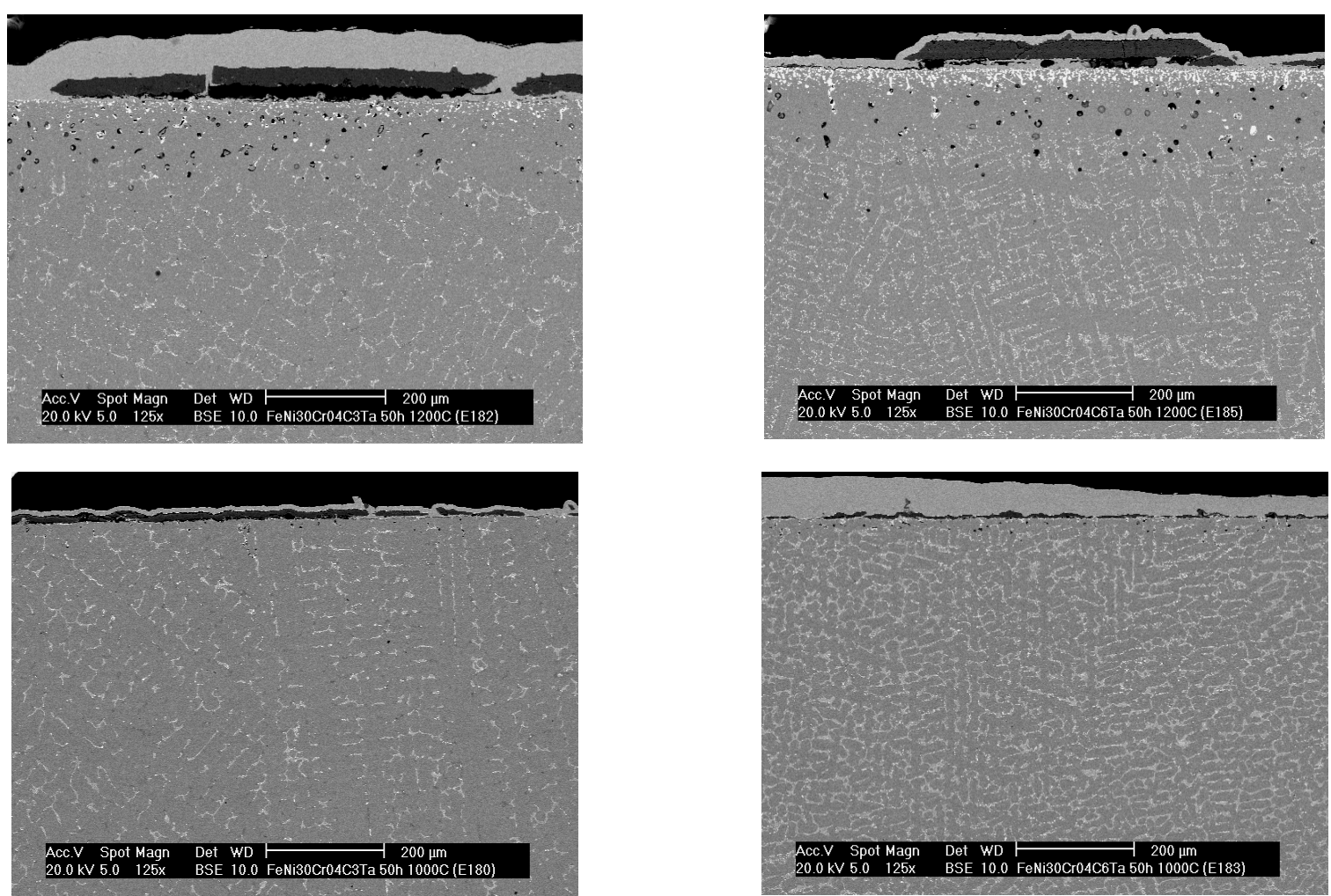

FeNi30Cr0.4C3Ta

FeNi30Cr0.4C6Ta

Fig. 2. Cross section metallographies of the two (Fe,Ni)-base alloys containing Ta after oxidation for 50 hours at $1,200^{\circ} \mathrm{C}$ (top) and $1,000^{\circ} \mathrm{C}$ (bottom)

The thickness of the chromia and of the internal tantalum oxides are shown in Table 2. Values obtained for a Ni30Cr0.4C3Ta and a Ni30Cr0.4C6Ta alloys [3], oxidized during 100 hours (and not 50 hours), are also added for a comparison purpose. They are supposed to be close to the oxide thicknesses that were measured in this previous work but after multiplication by the square root of ( 50 hours/100 hours $=2$ ). Indeed the growths of external oxides and also of internal oxides often fulfil a parabolic law.The corresponding values obtained for the ternary alloys $\mathrm{Fe} 30 \mathrm{Cr} 0.4 \mathrm{C}$ and $\mathrm{Ni30Cr0.4C} \mathrm{[2]} \mathrm{are} \mathrm{added} \mathrm{in} \mathrm{the} \mathrm{"0 \%} \mathrm{Ta"} \mathrm{column.}$

Table 2. Values of the average thicknesses of external chromia and of the equivalent $(\mathrm{Cr}, \mathrm{Ta})$ oxide assessed by image analysis (in each case average of 3 measures $+/-1$ std deviation)

\begin{tabular}{|c|c|c|c|c|c|c|}
\hline \multirow{2}{*}{$\begin{array}{l}\text { Av. thick. } \\
\text { of Cr oxide } \\
\text { Equ. thick. } \\
\text { of Ta oxide }\end{array}$} & \multirow{2}{*}{$\begin{array}{c}\mathrm{T} \\
\left({ }^{\circ} \mathrm{C}\right)\end{array}$} & \multirow{2}{*}{$\begin{array}{c}0 \% \mathrm{Ta} \\
\mathbf{C r}_{2} \mathbf{O}_{3} \\
(\boldsymbol{\mu m})\end{array}$} & \multicolumn{2}{|c|}{$3 \% \mathrm{Ta}$} & \multicolumn{2}{|c|}{$6 \% \mathrm{Ta}$} \\
\hline & & & $\begin{array}{c}\mathrm{Cr}_{2} \mathrm{O}_{3} \\
(\mu \mathrm{m})\end{array}$ & $\begin{array}{l}\text { (Cr,Ta) ox. } \\
\quad(\mu \mathrm{m})\end{array}$ & $\begin{array}{c}\mathrm{Cr}_{2} \mathrm{O}_{3} \\
(\mu \mathrm{m})\end{array}$ & $\begin{array}{l}\text { (Cr,Ta) ox. } \\
(\mu \mathrm{m})\end{array}$ \\
\hline \multirow{3}{*}{$\mathrm{Fe} 30 \mathrm{Cr} 0.4 \mathrm{C}$} & 1200 & $18 \pm 3$ & $32 \pm 6$ & $7.4 \pm 0.4$ & $16 \pm 4$ & $8.0 \pm 2.0$ \\
\hline & 1100 & $18 \pm 3$ & $22 \pm 2$ & $5.3 \pm 1.0$ & $19 \pm 3$ & $7.3 \pm 0.8$ \\
\hline & 1000 & $6.6 \pm 0.7$ & $\mathbf{1 1} \pm 1$ & $0.7 \pm 0.2$ & $8.3 \pm 1$ & $2.2 \pm 0.3$ \\
\hline \multirow{3}{*}{ FeNi30Cr0.4C } & 1200 & I & $30 \pm 2$ & $4.8 \pm 0.3$ & $31 \pm 2$ & $9.2 \pm 1.1$ \\
\hline & 1100 & I & $13 \pm 2$ & $1.8 \pm 0.3$ & $12 \pm 2$ & $4.4 \pm 0.9$ \\
\hline & 1000 & I & $\mathbf{1 0} \pm 1$ & $0.7 \pm 0.3$ & $6.2 \pm 2$ & $1.1 \pm 0.4$ \\
\hline \multirow{3}{*}{$\mathrm{Ni30Cr} 0.4 \mathrm{C}$} & 1200 & $21 \pm 3$ & n.o.r. & $5.9 \pm 0.7(4.2 *)$ & n.o.r. & $4.8 \pm 2.3(3.4 *)$ \\
\hline & 1100 & $11 \pm 1$ & $13 \pm 4(9.2 *)$ & $2.9 \pm 0.7(\mathbf{2 . 1 *})$ & $8.6 \pm 1.0\left(6.1^{*}\right)$ & $6.0 \pm 0.6(4.2 *)$ \\
\hline & 1000 & $\mathbf{4 . 6} \pm 0.7$ & $13 \pm 4(9.2 *)$ & $1.9 \pm 0.2(\mathbf{1 . 3 *})$ & $6.0 \pm 1.0(4.2 *)$ & $2.1 \pm 0.2\left(1.5^{*}\right)$ \\
\hline
\end{tabular}

(*: values deduced from the former multiplicated by $\sqrt{50 \mathrm{~h} / 100 \mathrm{~h}}$, i.e. divided by $\sqrt{2}$ )

(italic characters: the oxidation time for Ni30Cr0.4C3or6Ta was of 100h [3] and not 50 hours)

(n. o. $r$. : no external oxide remained on the sample after cooling) 
It appears that the chromia scale is thicker for the 3\%Ta-containing alloys than for the ternary alloys. But the presence of 6\% Ta involves a decrease of the chromia thickness which reaches again the values measured for the ternary alloys. Concerning the internal oxidation the equivalent thickness of tantalum oxide is more important for the $6 \%$ Ta-containing alloys than for the alloys with 3\% Ta. This equivalent tantalum oxide thickness also decreases when $\mathrm{Fe}$ is progressively replaced by $\mathrm{Ni}$ for a same Ta content. The same observation can be done for the $\mathrm{Cr}_{2} \mathrm{O}_{3}$ thickness.

Table 3 displays the average depths of the carbide-free zones. Concerning the Fe-base alloys, the carbide-free zone is more extended for a tantalum-free alloy than for its corresponding 3\%Tacontaining alloy, and the carbide-free zone depth goes on decreasing when the Ta content increases up to $6 \%$. Concerning the effect of a change of the base elements, it appears that the depth of the carbide-free zone reaches a minimal value when the contents of $\mathrm{Ni}$ and Fe are similar.

Table 3. Values of the average depths of the carbide-free zones

(in each case average of 3 measures $+/-1$ std deviation)

\begin{tabular}{|c|c|c|c|c|}
\hline $\begin{array}{c}\text { Average depth of } \\
\text { the carbide-free } \\
\text { zone }\end{array}$ & \multirow{2}{*}{ Temperature } & $0 \% \mathrm{Ta}$ & $3 \% \mathrm{Ta}$ & $6 \% \mathrm{Ta}$ \\
\cline { 3 - 5 } & & $\mathrm{d}_{\mathrm{cfz}}(\mu \mathrm{m})$ & $\mathrm{d}_{\mathrm{cfz}}(\mu \mathrm{m})$ & $\mathrm{d}_{\mathrm{cfz}}(\mu \mathrm{m})$ \\
\hline \multirow{3}{*}{$\mathrm{Fe} 30 \mathrm{Cr} 0.4 \mathrm{C}$} & $1200^{\circ} \mathrm{C}$ & $333 \pm 33$ & $272 \pm 11$ & $91 \pm 9$ \\
\cline { 2 - 5 } & $1100^{\circ} \mathrm{C}$ & $144 \pm 17$ & $98 \pm 2$ & $65 \pm 4$ \\
\hline \multirow{3}{*}{ FeNi30Cr0.4C } & $1000^{\circ} \mathrm{C}$ & $41 \pm 2$ & $36 \pm 6$ & $20 \pm 2$ \\
\cline { 2 - 5 } & $1200^{\circ} \mathrm{C}$ & 1 & $103 \pm 10$ & $107 \pm 6$ \\
\cline { 2 - 5 } & $1100^{\circ} \mathrm{C}$ & $/$ & $49 \pm 7$ & $11 \pm 4$ \\
\hline \multirow{3}{*}{$\mathrm{Ni30Cr0.4C}$} & $1200^{\circ} \mathrm{C}$ & $/$ & $19 \pm 5$ & $190 \pm 8(\mathbf{1 3 4} *)$ \\
\cline { 2 - 5 } & $1100^{\circ} \mathrm{C}$ & $143 \pm 2$ & $211 \pm 10(\mathbf{1 4 9 *})$ & $76 \pm 4(\mathbf{5 4} *)$ \\
\cline { 2 - 5 } & $1000^{\circ} \mathrm{C}$ & $26 \pm 3$ & $30 \pm 2(\mathbf{2 1 *})$ & $21 \pm 4(\mathbf{1 5 *})$ \\
\hline
\end{tabular}

(*: values deduced from the former multiplicated by $\sqrt{50 \mathrm{~h} / 100 \mathrm{~h}}$, i.e. divided by $\sqrt{2}$ )

(italic characters: the oxidation time for Ni30Cr0.4C3or6Ta was of $100 \mathrm{~h}$ [3] and not 50 hours)

(n. o. $r$. : no external oxide remained on the sample after cooling)

Thermogravimetry results. As examples, the mass gain curves obtained for the ( $\mathrm{Fe}, \mathrm{Ni})$-base alloys at all temperatures are presented in Fig. 3. A lot of curves are affected by one or several mass gain jumps due to local detachments of the external chromia layer. The Ta-containing alloys oxidize faster than the corresponding Ta-free alloys, while the 3\% Ta-containing alloys and the $6 \% \mathrm{Ta}-$ containing alloys have mass gain curves which are often very close to each other. An example of treatment of the mass gain results according to the $\{\mathrm{m} \times(\mathrm{dm} / \mathrm{dt})=\mathrm{Kp}-\mathrm{Kv} \times \mathrm{m}\}$ equation is given in the graph of Fig. 4. The values obtained for the two kinetic constants were tested by verifying that the experimental curve and the mathematical curve plotted with the values obtained for Kp and $\mathrm{Kv}$ are or not superimposed. Generally the constants were effectively validated.

The values obtained for the linear $\mathrm{K}_{1}$ constant are given in Table 4 , and the values of the parabolic constant $\mathrm{Kp}$ and of the volatilization constant Kv are presented in Table 5.

Very high values of both $\mathrm{Kp}$ and $\mathrm{Kv}$ were found for all the $\mathrm{Fe}$-base alloys for $1,200^{\circ} \mathrm{C}$, while they are on the contrary on the same order of magnitude as the (Fe,Ni)-base and Ni-base alloys for the two lower temperatures. For the parabolic constant of these Fe-base alloys at all temperatures, one can notice an increase of its value between $0 \%$ and $3 \% \mathrm{Ta}$, then decreasing between $3 \% \mathrm{Ta}$ and $6 \% \mathrm{Ta}$. This tendency globally remains for the (Fe,Ni)-base alloys and for the Ni-base ones, except for $1,000^{\circ} \mathrm{C}$ for which the parabolic constant does not vary with the Ta content for the $(\mathrm{Fe}, \mathrm{Ni})$-base alloys and decreases for the Ni-base alloys. Concerning the base elements, it can be noted that, almost at all temperatures, the $\mathrm{Kp}$ constant decreases when $\mathrm{Fe}$ is progressively replaced by $\mathrm{Ni}$. 
Concerning the Kv constant, there are globally an increase of its value when more Ta is present in the alloy (whatever the base element) and a decrease when $\mathrm{Fe}$ is replaced by $\mathrm{Ni}$ as base element.
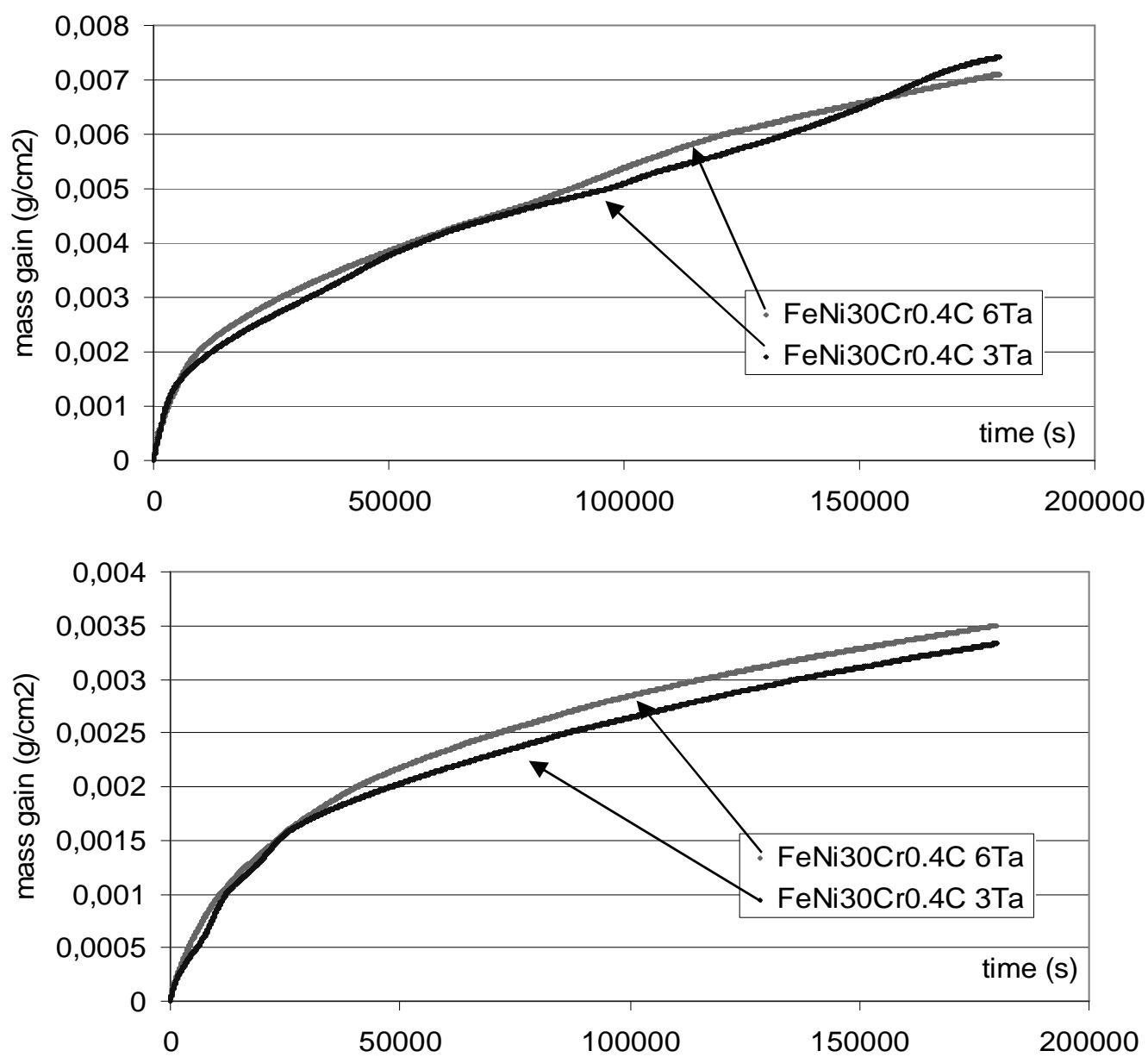

(a)

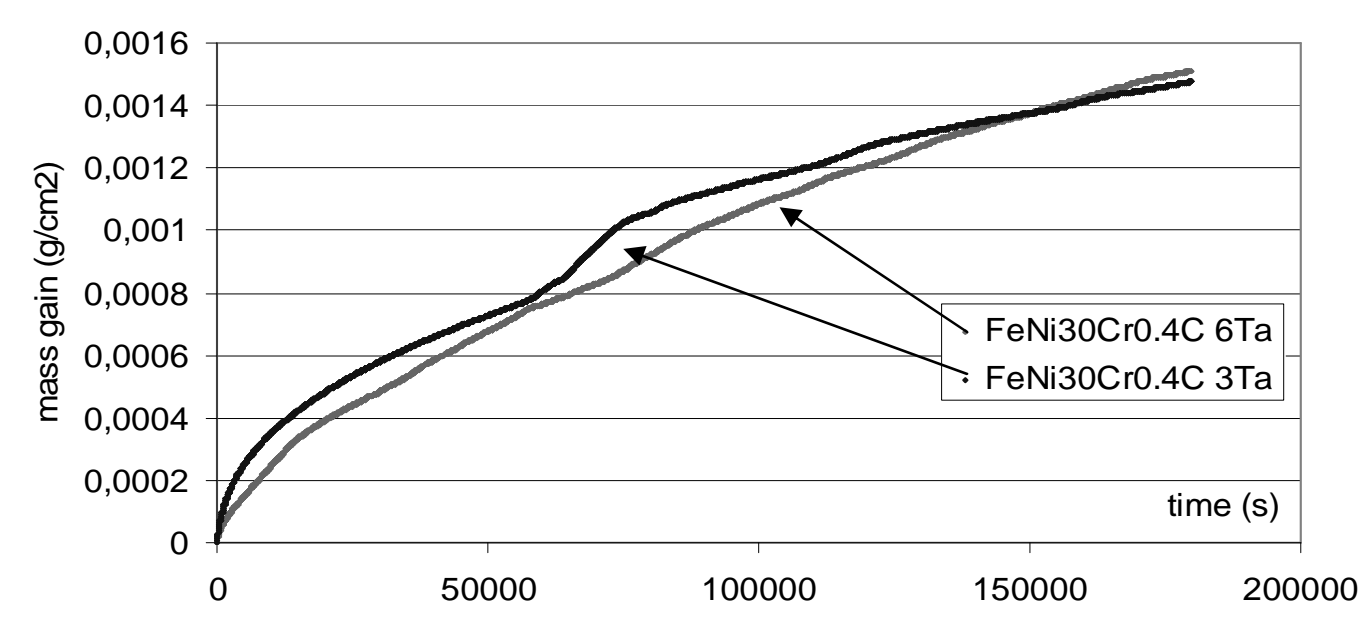

(b)

(c)

Fig. 3. Mass gain curves of the FeNi30Cr0.4CyTa (y = 3 and 6) alloys at 1,200 (a), 1,100 (b) and $1,000^{\circ} \mathrm{C}(\mathrm{c})$

Discussion. In these $\mathrm{Fe}$-base and (Fe,Ni)-base alloys the presence of Ta leads to similar densities of tantalum carbides, as already seen in Co-base alloys with the same $\mathrm{C}$ and Ta contents, and significantly higher than for Ni-base alloys [3]. Tantalum seems diffusing from the carbides towards the oxidation front to be oxidized in internal oxides, a phenomenon that promotes the development of a carbide-free zone. The depth of the latter is higher for a higher temperature of oxidation, but 
also higher for a lower Ta-content in the alloy. Thus, even if the equivalent thickness of tantalum oxide is generally slightly higher for a Fe-base alloy with a double Ta content, oxidation seems to involve almost the same quantity of tantalum, then promotes, in the Fe-base alloy with 3\% Ta, the disappearance of tantalum carbides over a double depth compared to the Fe-base alloy with $6 \%$ Ta.

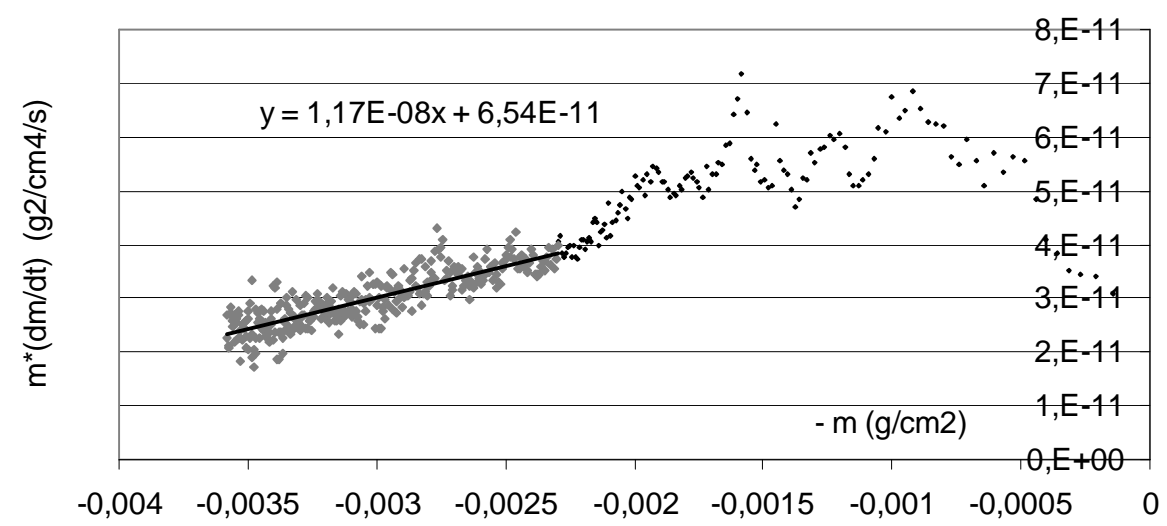

Fig. 4. $\{\mathrm{m} \times(\mathrm{dm} / \mathrm{dt})=\mathrm{Kp}-\mathrm{Kv} \times \mathrm{m}\}$-type treatment of the curve for FeNi30Cr0.4C6Ta at $1,100^{\circ} \mathrm{C}$

Table 4. Values of the transient linear $\mathrm{K}_{1}$ constant $\left(\mathrm{x} 10^{-8} \mathrm{~g} \cdot \mathrm{cm}^{-2} \cdot \mathrm{s}^{-1}\right)$

\begin{tabular}{|c|c|c|c|c|}
\hline $\mathrm{K}_{1}$ & temperature & $0 \% \mathrm{Ta}$ & $3 \% \mathrm{Ta}$ & $6 \% \mathrm{Ta}$ \\
\hline \multirow{3}{*}{$\mathrm{Fe} 30 \mathrm{Cr} 0.4 \mathrm{C}$} & $1200^{\circ} \mathrm{C}$ & 75 & 128 & 88 \\
\cline { 2 - 5 } & $1100^{\circ} \mathrm{C}$ & 29 & 29 & 48 \\
\cline { 2 - 5 } & $1000^{\circ} \mathrm{C}$ & 4.9 & 4.7 & 15 \\
\hline \multirow{3}{*}{$\mathrm{FeNi30Cr0.4C}$} & $1200^{\circ} \mathrm{C}$ & $/$ & 60 & 49 \\
\cline { 2 - 5 } & $1100^{\circ} \mathrm{C}$ & $/$ & 18 & 21 \\
\cline { 2 - 5 } & $1000^{\circ} \mathrm{C}$ & $/$ & 11 & 63 \\
\hline \multirow{3}{*}{ Ni30Cr0.4C } & $1200^{\circ} \mathrm{C}$ & 47 & 36 & 23 \\
\cline { 2 - 5 } & $1100^{\circ} \mathrm{C}$ & 20 & 10.5 & 3.7 \\
\cline { 2 - 5 } & $1000^{\circ} \mathrm{C}$ & 6.5 & 8.7 & \\
\hline
\end{tabular}

The ratio of carbide-free depths between the (Fe,Ni)-base alloys with 3\% $\mathrm{Ta}$ and $6 \% \mathrm{Ta}$, or between the Ni-base alloys with 3\% Ta and 6\% Ta, are not the same. A significant part of Ta is also contained in the matrix of these alloys while Ta is almost only present in the form of carbides in Fe-base alloys. The location of tantalum in the alloy seems to have consequences on the importance of internal oxidation, more precisely on the oxidation of tantalum. When this element is in grain boundaries as tantalum carbides (Fe-base alloys: higher equivalent thickness of tantalum oxide and deeper carbide-free zones) its diffusion towards the oxidation front seems easier than when a part of tantalum is in solid solution in the matrix ((Fe,Ni)-base and Ni-base alloys).

This oxidation of tantalum can be the reason of the higher mass gains at 1,200 and $1,100^{\circ} \mathrm{C}$ of the alloys containing tantalum, compared to the ones for the ternary alloys. Oxidation of tantalum can also be responsible of the difficulties that were sometimes met for the $(\mathrm{Kp}+\mathrm{Kv})$ determinations and validations, since this second oxidation phenomenon, without volatilization of the formed oxide, is not taken into account in the $\{\mathrm{m} \times \mathrm{dm} / \mathrm{dt}=\mathrm{Kp}-\mathrm{Kv} \times \mathrm{m}\}$ law [4]. Then, the simultaneous determination of both $\mathrm{Kp}$ and $\mathrm{Kv}$ is probably more accurate in the cases where tantalum is little involved in oxidation, i.e. when it is less present or when it is more difficult for it to diffuse. The latter condition is met for the lowest test temperatures, for the lowest tantalum contents, for Ni-base alloys rather than for (Fe,Ni)-base and Fe-base alloys, and for low carbon contents. 
The faster oxidation of the Fe-base alloys compared to the (Fe,Ni)-base and Ni-base alloys can be related to the crystallographic structure of the matrix at the test temperatures, i.e. BCC (ferritic) for the Fe-base alloys and FCC (austenitic) for the others. The nature of the major element itself also plays a role since oxidation is also slightly faster for a $(\mathrm{Fe}, \mathrm{Ni})$-base alloy than for its corresponding Ni-base alloy. The decrease of the parabolic constant of a Fe-base alloy when the Ta content is changed from 3 to $6 \%$, is also different to what it is encountered for the austenitic alloys. There is probably an effect of the BCC-FCC difference and/or of the base element difference here too. The obtained $\mathrm{Kv}$ values are in accordance with data from literature since, for austenitic alloys at $1,100^{\circ} \mathrm{C}$, they remain near 37 [5] and $83[6] \times 10^{-10} \mathrm{~g} \cdot \mathrm{cm}^{-2} \cdot \mathrm{s}^{-1}$, and at $1,200^{\circ} \mathrm{C}$ near 124 [5] and 280 [6] $x 10^{-10} \mathrm{~g} \cdot \mathrm{cm}^{-2} \cdot \mathrm{s}^{-1}$. It is also often the case for the ferritic alloys, excepted for $1,200^{\circ} \mathrm{C}$ for which the $\mathrm{Kv}$ values which were determined are very high.

Table 5. Values of $\mathrm{Kp}\left(\mathrm{x} 10^{-12} \mathrm{~g}^{2} \cdot \mathrm{cm}^{-4} \cdot \mathrm{s}^{-1}\right)$ and $\mathrm{Kv}\left(\mathrm{x} 10^{-10} \mathrm{~g} \cdot \mathrm{cm}^{-2} \cdot \mathrm{s}^{-1}\right)$ constants

\begin{tabular}{|c|c|c|c|c|}
\hline $\mathrm{Kp}$ & temperature & $0 \% \mathrm{Ta}$ & $3 \% \mathrm{Ta}$ & $6 \% \mathrm{Ta}$ \\
\hline \multirow{3}{*}{$\mathrm{Fe} 30 \mathrm{Cr} 0.4 \mathrm{C}$} & $1200^{\circ} \mathrm{C}$ & 499 & 844 & 696 \\
\hline & $1100^{\circ} \mathrm{C}$ & 59 & 131 & 119 \\
\hline & $1000^{\circ} \mathrm{C}$ & 6.3 & 87 & 13 \\
\hline \multirow{3}{*}{ FeNi30Cr0.4C } & $1200^{\circ} \mathrm{C}$ & 1 & 213 & 204 \\
\hline & $1100^{\circ} \mathrm{C}$ & I & 43 & 65 \\
\hline & $1000^{\circ} \mathrm{C}$ & I & 8.5 & 10 \\
\hline \multirow{3}{*}{$\mathrm{Ni30Cr0.4C}$} & $1200^{\circ} \mathrm{C}$ & 70 & 218 & 248 \\
\hline & $1100^{\circ} \mathrm{C}$ & 18 & 39 & 42 \\
\hline & $1000^{\circ} \mathrm{C}$ & 7.1 & 5.8 & 3.2 \\
\hline $\mathrm{Kv}$ & temperature & $0 \% \mathrm{Ta}$ & $3 \% \mathrm{Ta}$ & $6 \% \mathrm{Ta}$ \\
\hline \multirow{3}{*}{$\mathrm{Fe} 30 \mathrm{Cr} 0.4 \mathrm{C}$} & $1200^{\circ} \mathrm{C}$ & 514 & 436 & 770 \\
\hline & $1100^{\circ} \mathrm{C}$ & 73 & 98 & 137 \\
\hline & $1000^{\circ} \mathrm{C}$ & 27 & 348 & -3.6 \\
\hline \multirow{3}{*}{ FeNi30Cr0.4C } & $1200^{\circ} \mathrm{C}$ & 1 & 213 & 200 \\
\hline & $1100^{\circ} \mathrm{C}$ & 1 & 53 & 117 \\
\hline & $1000^{\circ} \mathrm{C}$ & I & 51 & 23 \\
\hline \multirow{3}{*}{$\mathrm{Ni30Cr0.4C}$} & $1200^{\circ} \mathrm{C}$ & 82 & 156 & 235 \\
\hline & $1100^{\circ} \mathrm{C}$ & 58 & 26 & 70 \\
\hline & $1000^{\circ} \mathrm{C}$ & 32 & 16 & 24 \\
\hline
\end{tabular}

Bold characters: excellent fit between the experimental mass gain curve and the mathematical one

Normal characters: good fit between the experimental mass gain curve and the mathematical one

Italic characters: not good fit between the experimental mass gain curve and the mathematical one

\section{Conclusion}

When present in Fe-base and (Fe,Ni)-base carbon-containing alloys, tantalum leads to a TaC carbides network which seems to influence the high temperature oxidation behaviour. Their mass gains are higher than for Ta-free alloys, especially for the highest temperatures. Moreover the oxidation of $\mathrm{Ta}$ leads to difficulties for determining the parabolic and chromia volatilization constants by using the $\{\mathrm{m} \times \mathrm{dm} / \mathrm{dt}=\mathrm{Kp}-\mathrm{Kv} \times \mathrm{m}\}$ - treatment. This is particularly true in the case of iron-base alloys in which the diffusion of Ta towards the oxidation front is the easiest because of its availability in grain boundaries. Thus, an efficient reinforcement by tantalum carbides is probably easier to obtain in $\mathrm{Fe}$-base and (Fe,Ni)-base alloys than in Ni-base alloys, but unfortunately with a significant decrease of the resistance against high temperature oxidation of alloys. 


\section{References}

[1] P. Kofstad: High Temperature Corrosion (Elsevier, 1988)

[2] P. Berthod: to be published in Ann. Chim. - Sci. Mater., 33 (2008).

[3] P. Berthod, L. Aranda and C. Vébert: Ann. Chim. - Sci. Mater., 31 (2006), p. 213.

[4] P. Berthod: Oxidation of Metals, 64 (2005), p. 235.

[5] W.C. Hagel: Transactions of the ASM, 56 (1963), p. 583.

[6] C.A. Stearns, F.J. Kohl and G.C. Fryburg: J. Electrochem. Soc., 121/7 (1974), p. 945. 